\title{
2011s-04
}

\section{Minimum Wage and Job Complexity}

\author{
Samir Amine, Pedro Lages Dos Santos
}

Série Scientifique
Scientific Series

\section{Montréal \\ Janvier 2011}

(C) 2011 Samir Amine, Pedro Lages Dos Santos. Tous droits réservés. All rights reserved. Reproduction partielle permise avec citation du document source, incluant la notice $\odot$.

Short sections may be quoted without explicit permission, if full credit, including $@$ notice, is given to the source.

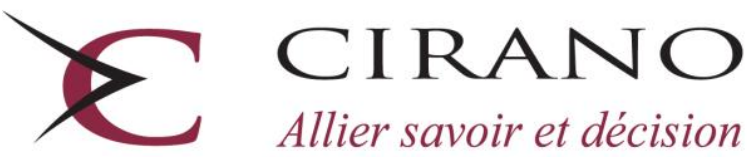

Centre interuniversitaire de recherche en analyse des organisations 


\section{CIRANO}

Le CIRANO est un organisme sans but lucratif constitué en vertu de la Loi des compagnies du Québec. Le financement de son infrastructure et de ses activités de recherche provient des cotisations de ses organisations-membres, d'une subvention d'infrastructure du Ministère du Développement économique et régional et de la Recherche, de même que des subventions et mandats obtenus par ses équipes de recherche.

CIRANO is a private non-profit organization incorporated under the Québec Companies Act. Its infrastructure and research activities are funded through fees paid by member organizations, an infrastructure grant from the Ministère du Développement économique et régional et de la Recherche, and grants and research mandates obtained by its research teams.

\section{Les partenaires du CIRANO}

Partenaire majeur

Ministère du Développement économique, de l'Innovation et de l'Exportation

\section{Partenaires corporatifs}

Banque de développement du Canada

Banque du Canada

Banque Laurentienne du Canada

Banque Nationale du Canada

Banque Royale du Canada

Banque Scotia

Bell Canada

BMO Groupe financier

Caisse de dépôt et placement du Québec

Fédération des caisses Desjardins du Québec

Financière Sun Life, Québec

Gaz Métro

Hydro-Québec

Industrie Canada

Investissements PSP

Ministère des Finances du Québec

Power Corporation du Canada

Raymond Chabot Grant Thornton

Rio Tinto

State Street Global Advisors

Transat A.T.

Ville de Montréal

\section{Partenaires universitaires}

École Polytechnique de Montréal

HEC Montréal

McGill University

Université Concordia

Université de Montréal

Université de Sherbrooke

Université du Québec

Université du Québec à Montréal

Université Laval

Le CIRANO collabore avec de nombreux centres et chaires de recherche universitaires dont on peut consulter la liste sur son site web.

Les cahiers de la série scientifique (CS) visent à rendre accessibles des résultats de recherche effectuée au CIRANO afin de susciter échanges et commentaires. Ces cahiers sont écrits dans le style des publications scientifiques. Les idées et les opinions émises sont sous l'unique responsabilité des auteurs et ne représentent pas nécessairement les positions du CIRANO ou de ses partenaires.

This paper presents research carried out at CIRANO and aims at encouraging discussion and comment. The observations and viewpoints expressed are the sole responsibility of the authors. They do not necessarily represent positions of CIRANO or its partners. 


\title{
Minimum Wage and Job Complexity
}

\author{
Samir Amine ${ }^{*}$ Pedro Lages Dos Santos ${ }^{\dagger}$
}

\section{Résumé / Abstract}

Cet article vise à mieux comprendre comment les régulations publiques modifient le comportement des agents en termes de sélectivité et comment les entreprises adaptent les caractéristiques de leurs emplois en fonction de l'état du marché du travail et, notamment du niveau de qualification de la population active. En utilisant un modèle d'appariement dans lequel les travailleurs sont différenciés verticalement et la nature des emplois est endogène, nous montrons que la revalorisation du salaire minimum peut favoriser l'embauche des qualifiés en rendant les entreprises plus sélectives et les emplois plus complexes.

Mots clés : Salaire minimum, productivité et participation.

This article aims to understand how public policies affect the behavior of agents in term of selectivity. In other words, we explain how the state of the labour market and, in particular qualification level of workers, affects technological choices of firms. Using a matching model in which workers are vertically differentiated and where the nature of jobs is endogenous, we show that an increase in minimum wage can enhance the recruiting of skilled workers by making firms more selective and jobs more complex.

Keywords: Minimum Wage, Productivity, Participation.

Code JEL : J64, J65

\footnotetext{
* Université du Québec en Outaouais, Pavillon Alexandre-Taché, 283 boulevard Alexandre Taché, bureau C3805, Case postale 1250, Gatineau, Québec, Canada, J8X 3X7, samir.amine @ uqo.ca and CIRANO, 2020 University St., Suite 2500, Montréal, Québec, H3A2A5, samir.amine@ cirano.qc.ca. $\dagger$ Université du Havre, Faculté des Affaires internationales, 25 rue Philippe Lebon, BP. 420, 76057 Le Havre Cedex, France, pedro.lages@univ-lehavre.fr
} 


\section{Introduction}

The deteriorating labour market situation of the less qualified over the past twenty years has characterized most developed countries. This has led many experts and international organizations, including the OECD, to focus on the lack of the labour market flexibility in European countries (Krugman, 1993; Manacorda and Petrongolo, 1999) and to recommend that these countries should soften their legislation. Labour market legislation which varies from one country to another would, according to the OECD, be an important explanation for the observed differences between European and American unemployment and wages inequalities. In particular, the OECD emphasizes the relatively high costs of layoffs, minimum wage and the role of trade unions.

Several arguments have been presented to explain the rising inequality between skilled and unskilled worker earnings, namely technical progress and international trade. However, the theoretical and empirical literature (Acemoglu, 2002, 2003; Aghion and Howitt, 2002) have considered the first as the most crucial.

In the literature, biased technical progress is generally regarded as a exogenous parameter which determines the state of the labour market (Gautier and Teulings, 2004; Nickell, 2004). In this context, Acemoglu (1999), Albrecht and Vroman (2002) and Gautier (1999) have constructed models in which firm qualification needs are endogenous. These authors have focused on vertical differentiation of workers and therefore on the question of job complexity. However, in these models worker heterogeneity is binary (qualified / not qualified) and firms choice discret. As a result, productivity of a skilled job filled by a qualified worker does not depend on the state of the labour market. In other words, job complexity remains essentially exogenous.

The contribution of this paper comes from the way we study the interactions between technological choices of firms and labour market policies. The existing literature treats productivity inequalities as given and tries to find the most effective policies to reduce the gaps between workers (Marimon and Zilibotti, 1999). We consider that firms react to public policies by changing their technological choices according to the qualification level of workers. The perspective is thus reversed. Instruments like unemployment benefits and minimum wage not only affect labour market performance, but also firms' technological 
choices. Theses choices are at the very source of inequalities these instruments are supposed to reduce.

We use a dynamic matching model (Pissarides, 2000) in which heterogeneous workers are vertically differentiated by their qualification level (Strand, 2000 and 2002). On the other hand, firms are supposed identical and offer a single homogeneous job. The hiring process between the two agents is formalized by a constant returns function.

Workers productivity depends both on their qualification level and on the degree of job complexity. In accordance to intuition, we suppose that only qualified workers take advantage of job complexity. In other words, we account for the complementarity between complexity and qualification level. In this context, only workers with sufficient qualification level will participate in the labour market. An ability threshold is thus defined. All workers whose qualification level is lower than this threshold are considered not employable and are excluded from the labour market. We will show that this threshold plays a key role in the determination of job complexity.

In this framework, we study the effects of unemployment benefits and of minimum wage on productivity and on labour market participation. We show that an increase in minimum wage would make firms more selective by requiring a higher ability threshold for recruiting workers.

With the minimum wage, all workers whose productivity is low will be excluded from the labour market because firms refuse to recruit them. As a result, an increase in the minimum wage leads to a decrease in labour market participation. Considering that the recruitment of qualified workers becomes easier, firms in this economy respond to this increased selectivity by creating more complex jobs. The characteristics of created jobs will be adapted for higher skill workers, leading to an improvement in matching quality, and thus productivity. In this context, the minimum wage can be presented as a public policy instrument for regulating job assignment and for improving labour market efficiency.

Comparative statics also suggests that an increase in unemployment benefits makes firms and employable workers more selective by requiring a higher ability threshold. As a result, firms choose to increase job complexity, which has a positive effect on productivity. However, and in spite of matching quality im- 
provements, the labour market participation decreases, while the unemployment rate rises.

The rest of paper is organized as follows. The model and the market structure are presented in Section 2. Then, solving of the model and the definition of its equilibrium are discussed in Section 3. We define and study the comparative statics properties of the model in Sections 4 and 5. Finally, the paper concludes in Section 6.

\section{The Model}

Consider an economy populated by a large exogenous number of workers and a large endogenous number of firms. Each firm offers a single job. Firms and workers are risk neutral and have the same rate of time preference denoted by $r$.

Workers are vertically differentiated by their qualification level and have an infinite horizon. Each worker's ability $z$ is a constant, implying that productivity differences are purely general. Among workers population, $z$ is distributed according to a continuous distribution, $G(z)$, with support $z \in\left[z_{\min }, Z\right]$. The density of $G(z)$ is denoted by $g(z)$.

On the other hand, firms in this economy are identical. The exogenous job destruction rate is $s$. Nevertheless, we assume firm free-entry in order to maintain a fixed number of firms at the stationary state.

In addition, each firm- $i$ of this economy requires a minimal ability (qualification level), called $\hat{z}_{i}$, for her future worker. Indeed, all workers with an ability below $\hat{z}_{i}$ are excluded from the labour market and will be considered not employable.

\subsection{Job Complexity and Productivity}

A firm that enters the labour market with a vacant job, must define the degree of complexity of this job in order to maximize its value. This endogenous

determination of production technology based on the market labour conditions is a key point of our analysis. 
In this context, we assume that the productivity of a job- $i$ depends both on the degree of complexity and on the ability (i.e. qualification level) of the worker who is occupying it. Formally, productivity of a job- $i$, noted $y_{i}\left(a_{i}, z\right)$, is considered as a linear and increasing function of ability $z$ :

$$
y_{i}\left(a_{i}, z\right)=A\left(a_{i}\right)+a_{i} z
$$

In this equation, the endogenous variable $a_{i}\left(a_{i} \geq 0\right)$ measures the degree of complexity of the job offered by firm- $i$. Intuition suggests that an increase in complexity must raise skilled workers productivity while decrease unskilled workers productivity. It is easy to see that, formally, this hypothesis requires that $A\left(a_{i}\right)$ be a decreasing function. In order to check this hypothesis, we consider the specific ability level, noted $\tilde{z}_{i}$, such that an increase in $a_{i}$ leaves productivity $y_{i}\left(a_{i}, \tilde{z}_{i}\right)$ unchanged: :

$$
\frac{\partial y_{i}\left(a_{i}, \tilde{z}_{i}\right)}{\partial a_{i}}=0 \quad \Longleftrightarrow \quad \tilde{z}_{i}=-A^{\prime}\left(a_{i}\right)>0
$$

By substitution, we get

$$
\frac{\partial y_{i}\left(a_{i}, z\right)}{\partial a_{i}}=z_{i}-\tilde{z}_{i}
$$

We observe that an increase in $a_{i}$ leads to a rise in productivity for workers whose ability is higher than $\tilde{z_{i}}$ and to a decline in productivity for workers whose ability is less than $\tilde{z_{i}}$. Moreover, it seems natural to consider that the proportion of workers whose ability allows for an increase in degree of complexity decreases (increase of $\tilde{z}_{i}$ ) when complexity increases. In other words, a continuing rise in complexity has a negative effect on the proportion of employable workers. This boils down to having a concave $A\left(a_{i}\right)$ function:

$$
\frac{d \tilde{z}_{i}}{d a_{i}}=-A^{\prime \prime}\left(a_{i}\right)>0
$$

As noted above, we are only interested in the effects of technological biased (Figure 1). In this case, increasing the degree of complexity implies, on the one hand, a rise in productivity of the highly skilled workers, and on the other hand, a decrease in productivity of unskilled workers. Formally, this boils down 
to admit that the threshold ability $\hat{z}_{i}$ is lower than $\tilde{z}_{i}$. We conclude that:

$$
\frac{\partial y_{i}\left(a_{i}, \hat{z}_{i}\right)}{\partial a_{i}}<0 \quad \Longleftrightarrow \quad \hat{z}_{i}+A^{\prime}\left(a_{i}\right)<0 \quad \Longleftrightarrow \quad \hat{z}_{i}<\tilde{z}_{i}
$$

In fact, each firm- $i$ decides on the degree of complexity by taking into account that only qualified workers can take advantage of an increase in complexity $A^{\prime}\left(a_{i}\right)<0$. This complementarity relation between qualification and technology has been treated in several theoretical (Author and al., 1998, Funk and Vogel, 2004) and empirical (Bound and Johnson, 1992; Berman and al. 1994) papers. In a general equilibrium framework, Acemoglu (1998) shows also that only skilled workers are able to put in place new technologies within firms.

To summarize, setting the minimum ability level (qualification level) allows the firm to determine, on average, the characteristics of his future worker (low or high $z$ level) and to adopt a technological choice which corresponds to the ability level of workers who are able to occupy its vacant job.

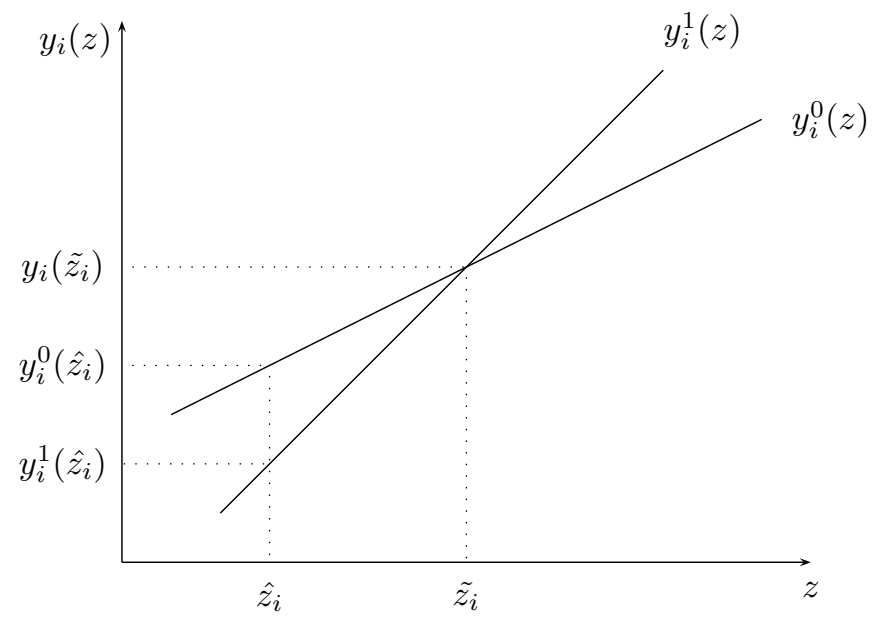

Figure 1: Job Complexity and Productivity 


\subsection{Hiring Process}

There are frictions in the labour market that stop instantaneous matching of employable unemployed workers and vacant jobs. Let, $\theta$, represent the labour market tightness (i.e. the ratio of vacant jobs, $V$, to employable unemployed workers $U$ ). Meetings between firms with a vacant job and employable unemployed workers are summarized by a constant-returns matching function (Pissarides, 2000).

Formally, the matching function, noted $\pi(V, U)$, is an homogenous function of degree 1 and is increasing function in $V$ and $U$. Thus, the probability for a firm to meet an employable worker is :

$$
q=\frac{\pi(V, U)}{V}=\pi\left(1, \frac{1}{\theta}\right)=q(\theta)
$$

It is obvious that this probability is decreasing in $\theta$. Owing to the congestion effect, a rise in the number of vacant jobs has a negative impact on the probability to fill a job. Concerning workers, the hiring probability, noted $p$, is written as follows :

$$
p=\theta q(\theta)=p(\theta)
$$

Contrary to $q(\theta)$, the probability that an employable worker finds a job is an increasing function of $\theta$. In other words, a rise in the number of vacant jobs provides workers with more opportunities to find a job.

\subsection{Intertemporal Utilities and Profits}

In the following, we restrict the analysis to a symmetric stationary state, where all firms but $i$ have set the same degree of complexity $a$, as well as the same ability threshold $\hat{z}$. At this stage, the pair $(a, \hat{z})$ is seen as exogenous. In the next section, we will show that the choice of firm- $i,\left(a_{i}, \hat{z}_{i}\right)$, is derived from the optimization of the vacant job value.

Let's consider the expected lifetime utility of an employable worker with ability $z$. At the stationary state, if this worker holds job- $i$, his/her lifetime utility $W_{i}(z)$ depends on his wage $w_{i}(z)$ and on the destruction rate $s$. 
We assume that unemployed workers income is composed of unemployment benefits $b$ and of domestic productivity $\mu$. Their expected lifetime utility $W_{u}(z)$, depends on the probability $p(\theta)$ of finding a job. As a result, in the stationary state, utilities $W_{i}(z)$ and $W_{u}(z)$ satisfy :

$$
\begin{gathered}
r W_{i}(z)=w_{i}(z)-s\left(W_{i}(z)-W_{u}(z)\right) \\
r W_{u}(z)=b+\mu+p(\theta)\left(W(z)-W_{u}(z)\right)
\end{gathered}
$$

where $W(z)$ is the lifetime utility of workers with ability level $z$ when holding a job different from $i$. As firms are very numerous, the probability of unemployed workers getting job- $i$ is almost zero.

We consider that the firms jobs are either vacant or filled. The value of job- $i$ filled by a worker with ability $z, J_{i}(z)$, depends on the net instantaneous income $\left(y_{i}\left(a_{i}, z\right)-w_{i}(z)\right)$ and on the future profits taking into account that the firm can die at any time with probability $s$. It satisfies:

$$
r J_{i}(z)=y_{i}\left(a_{i}, z\right)-w_{i}(z)-s\left(J_{i}(z)-J_{v i}(z)\right)
$$

As long its job is not filled, firm- $i$ must invest $c$ to create this job and to look for a worker. Furthermore, opening a new job is more profitable if the probability $q(\theta)$ is high. The value of a vacant job- $i$ depends on the conditional expected value $\bar{J}_{i}$ and given by:

$$
\bar{J}_{i}=\frac{1}{1-G\left(\hat{z_{i}}\right)} \int_{\hat{z}_{i}}^{Z} J_{i}(z) g(z) d z
$$

Firm- $i$ is too small to lead workers of lower ability than $\hat{z}$ to seek for a job. This means that the threshold $\hat{z}_{i}$ cannot be lower than $\hat{z}$. Under this condition, the value $J_{v i}$ satisfies :

$$
r J_{v i}=-c+\frac{q(\theta)}{1-G(\hat{z})} \int_{\hat{z}_{i}}^{Z}\left(J_{i}(z)-J_{v i}\right) g(z) d z
$$

Taking into account of the free-entry assumption, we admit that new jobs will be created until the optimal value of a vacant job be equal to zero. In addition, the job- $i$ average productivity $\bar{y}_{i}$ and average wage $\bar{w}_{i}$ are given by: 


$$
\begin{gathered}
\bar{y}_{i}=\frac{1}{1-G\left(\hat{z_{i}}\right)} \int_{\hat{z_{i}}}^{Z} y_{i}\left(a_{i}, z\right) g(z) d z \\
\bar{w}_{i}=\frac{1}{1-G\left(\hat{z_{i}}\right)} \int_{\hat{z_{i}}}^{Z} w_{i}(z) g(z) d z
\end{gathered}
$$

\subsection{Wage Bargaining and Surplus Sharing}

In accordance with usual matching models, surplus created by a firm/worker is divided between the two agents according to their respective bargaining strength. However, here, Generalized Nash rule is constrained by giving the worker a wage higher than the minimum wage $(m)$. In fact, if $\beta(0<\beta<1)$ represents the workers bargaining strength, the optimization program for firm- $i$ is:

$$
\operatorname{Max}\left(W_{i}(z)-W_{u}(z)\right)^{\beta}\left(J_{i}(z)-J_{v i}\right)^{(1-\beta)} \quad \text { s.c }: w_{i}(z) \geq m
$$

This program has two types of solutions depending on the minimum wage level. First, for small values of this minimum wage, the constraint is not binding. Therefore, the global surplus, noted $S_{i}(z)$, is divided between the two agents according to the Nash rule:

$$
\begin{gathered}
W_{i}(z)-W_{u}(z)=\beta\left(W_{i}(z)-W_{u}(z)+J_{i}(z)-J_{v i}\right)=\beta S_{i}(z) \\
J_{i}(z)-J_{v i}=(1-\beta)\left(W_{i}(z)-W_{u}(z)+J_{i}(z)-J_{v i}\right)=(1-\beta) S_{i}(z)
\end{gathered}
$$

In this first case, the wage setting is free and the ability threshold $\hat{z_{i}}$ cancels the global surplus.

On the contrary, if minimum wage is high (that is the case which we are interest in), the constraint is binding for less productive matches (i.e. for workers with low qualification). The solution to (15) depends on the ability of the worker who fills the job. We consider the ability transition level, noted $z_{i}^{m}$, such that the Generalized Nash rule implies a bargained wage equal to minimum wage $m$ :

$$
w_{i}\left(z_{i}^{m}\right)=m
$$

Two systems of wage setting should be distinguished. In the first system, qualification level of a worker who holds a job is superior to $z_{i}^{m}$. In this case, 
wage is determined by the Nash rule and workers rent satisfies:

$$
W_{i}(z)-W_{u}(z)=\frac{w_{i}(z)-r W_{u}(z)}{r+s}
$$

Taking into account of the surplus sharing rule (equation (17)) and of the value of filled job- $i$, we deduce the following expression for $\left(J_{i}(z)-J_{v i}\right)$ on the interval $\left[z_{i}^{m}, Z\right]$ :

$$
J_{i}(z)-J_{v i}=\frac{(1-\beta)\left(y_{i}\left(a_{i}, z\right)-r\left(J_{v i}+W_{u}(z)\right)\right)}{r+s}
$$

On the contrary, in the second system, qualification level is inferior to $z_{i}^{m}$ and the Nash rule generates a low wage. In this case, the worker who fills a job- $i$ receives a minimum wage. Thus, a firm makes the following profit :

$$
J_{i}(z)-J_{v i}=\frac{y_{i}\left(a_{i}, z\right)-m-r J_{v i}}{r+s}
$$

We know that productivity of job- $i$ is an increasing function of qualification level and that surplus of firm- $i\left(J_{i}(z)-J_{v i}\right)$ must be positif. Considering equation (21), the ability threshold $\hat{z}_{i}$ must satisfy the following condition:

$$
y_{i}\left(a_{i}, \hat{z}_{i}\right) \geq m+r J_{v i}
$$

Formally, this condition implies that $\hat{z}_{i}$ maximizes the value of vacant job- $i$ under the constraint that $\hat{z}_{i} \geq \hat{z}$. At the symmetric state, this inequality will be necessarily binding. Taking into account of the free-entry assumption, we obtain:

$$
y(a, \hat{z})=m
$$

An increase in minimum wage has a positive effect on minimal productivity (marginal worker's productivity). In other words, firms become more selective by requiring a higher $\hat{z}$. Consequently, the proportion of not employable workers rises and the participation rate in the labour market, noted $\tau(\tau=1-G(\hat{z}))$, decreases. As a consequence, it appears that the introduction of a minimum wage can be a source of labour market efficiency, by shifting the job structure in favor of qualified workers. 
In the stationary equilibrium, the number of workers who lose their job must equal the number of unemployed workers who find a job. This equilibrium condition implies:

$$
p(\theta) U=s L=s(N-U)
$$

Thus, the equilibrium unemployment rate $u$ is a function of the recruiting probability $p(\theta)$ :

$$
u=\frac{s}{s+p(\theta)}
$$

For a given level of $p(\theta)$, an increase in the destruction rate $s$ leads to a rise in the equilibrium unemployment rate. On the contrary, this latter is a decreasing function of the recruiting probability $p(\theta)$ (for a given level of $s$ ).

\section{Model Equilibrium}

Solving the model consists of establishing interactions at the stationary equilibrium, between labour market tightness $\theta$, ability transition $z^{m}$, degree of com-

plexity $a$ and ability threshold $\hat{z}$. We first study and specify the optimal degree of job complexity, and then, describe wage setting and job creation processes.

\subsection{Optimal Choice of Job Complexity}

When entering the labour market, firm- $i$ decides on the degree of complexity of the created job $\left(a_{i}\right)$. This optimal choice results from the maximization of the asset value $J_{v i}$. According to equations (20) and (21), we deduce an expression for the value of the vacant job $J_{v i}$ depending on choice variables of firm- $i$ :

$$
\begin{gathered}
r J_{v i}=-c+\frac{q(\theta)}{(r+s)(1-G(\hat{z}))}\left[\int_{\hat{z}_{i}}^{z_{i}^{m}}\left(y_{i}\left(a_{i}, z\right)-m-r J_{v i}\right) g(z) d z+(1-\beta)\right. \\
\left.\int_{z_{i}^{m}}^{Z}\left(y_{i}\left(a_{i}, z\right)-r\left(W_{u}(z)+J_{v i}\right)\right) g(z) d z\right]
\end{gathered}
$$


At the symmetric equilibrium, maximization of (26) with respect to a degree of job complexity $a_{i}$, implies:

$$
A^{\prime}(a)\left[(1-G(\hat{z}))-\beta\left(1-G\left(z^{m}\right)\right)\right]=-\int_{\hat{z}}^{z^{m}} z g(z) d z-(1-\beta) \int_{z^{m}}^{Z} z g(z) d z
$$

The productivity of workers receiving a minimum wage acts more strongly on the expected profits than the one of qualified workers receiving a bargained wage. Thus, the degree of complexity does not maximize average productivity. As a result, we can verify that an increase of the ability transition $z^{m}$ reduces the job complexity when $a$ has a negative effect on the productivity of workers receiving a minimum wage:

$$
A^{\prime}(a)+z^{m}<0
$$

This expression can be explained by the fact that going from bargained wage to minimum wage reduces the impact of increasing job complexity on expected profits. Since $A(a)$ is concave, we have that:

$$
\frac{d a}{d z^{m}}=\frac{-A^{\prime \prime}(a)\left[1-G(\hat{z})-\beta\left(1-G\left(z^{m}\right)\right)\right]}{\beta\left[A^{\prime}(a)+z^{m}\right]}<0
$$

If wage setting is free (i.e. absence of minimum wage), ability transition and ability threshold are equal $\left(z^{m}=\hat{z}\right)$ (Amine, 2006).

\subsection{Job Creation}

We use equations (16) and (17) in order to establish interactions, at the stationary equilibrium, between labour market tightness, ability transition, degree

of complexity and ability threshold. We obtain an expression for the workers' share in the global surplus:

$$
W(z)-W_{u}(z)=\frac{\beta}{1-\beta} \frac{y(a, z)-w(z)}{r+s}
$$

Using equations (8) and (9), we deduce a second expression for workers' share in the global surplus:

$$
W(z)-W_{u}(z)=\frac{w(z)-b-\mu}{r+s+p(\theta)}
$$


From these two expressions of workers' share $\left(W(z)-W_{u}(z)\right)$, we establish that (for $z=z^{m}$ ):

$$
\frac{\beta}{1-\beta} \frac{y\left(a, z^{m}\right)-m}{r+s}=\frac{m-b-\mu}{r+s+p(\theta)}
$$

We show that, for a given level of $\theta$ and $z^{m}$, raising the minimum wage has a positive and proportional impact on the minimal productivity (equation (23)), making the proportion of workers excluded from the labour market higher. As a consequence, job complexity becomes more profitable.

Raising of unemployment benefits, which increases bargained wages, reduces ability transition $z^{m}$. Thus, for a given level of $\hat{z}$, the proportion of workers receiving the minimum wage decreases.

Since we assume firm free-entry, we can establish the following expression for the job creation process:

$$
\bar{w}=\bar{y}-\frac{(r+s) c}{q(\theta)}
$$

Moreover, minimum wage satisfies:

$$
\bar{w}=\frac{G\left(z^{m}\right)-G(\hat{z})}{1-G(\hat{z})} m+\frac{1}{1-G(\hat{z})} \int_{z^{m}}^{Z} w(z) g(z) d z
$$

Substituting equation (33) in (34), we obtain an other expression between endogenous variables of the model:

$$
\begin{gathered}
\bar{y}-\frac{(r+s) c}{q(\theta)}=\frac{G\left(z^{m}\right)-G(\hat{z})}{1-G(\hat{z})} m+\frac{1-G\left(z^{m}\right)}{1-G(\hat{z})}\left[\frac{(b+\mu)(r+s)(1-\beta)}{r+s+\beta p(\theta)}+\right. \\
\left.\frac{\beta(r+s+p(\theta))}{r+s+\beta p(\theta)} \frac{1}{1-G\left(z^{m}\right)} \int_{z^{m}}^{Z} y(a, z) g(z) d z\right]
\end{gathered}
$$

By differentiation of this expression, we show that, for a given level of $\theta$ and $a$, an increase in the minimum wage has a positive effect on the proportion of workers receiving this minimum wage, and hence rises the ability transition $z^{m}$. 


\subsection{Equilibrium}

The labour market equilibrium is defined as follows:

Definition 1 The labour market equilibrium is a set of variables $\left(a^{*} ; \hat{z}^{*} ; \theta^{*} ; z^{m *}\right)$ which jointly satisfy equations (23), (27), (32) and (35).

In order to facilitate comparative statics study, it is convenient to use a two-dimensional space by treating threshold ability $\hat{z}$ and ability transition $z^{m}$ as implicit functions of complexity $a$. Then, by substitution in equations (32) and (35), we get two expressions between the labour market tightness $\theta$ and job complexity $a$.

From equations (23) and (27), we deduce that equilibrium expression (32) allows to write the labour market tightness as an implicit and decreasing function of complexity $a$. In the $(\theta, a)$ space, this function $(\theta=C E(a,)$.$) is represented$ by a decreasing curve, noted $(C E)$ (Figure 2).

We now consider equilibrium expression (35). It is easy to verify that, according to (35), average productivity and the labour market tightness are positively correlated. However, we have established that average productivity is an increasing function of complexity. As a consequence, equation (35) allows to write the labour market tightness $\theta$ as an implicit and increasing function of complexity $a$. This second function $(\theta=J C(a,)$.$) is represented by an increas-$ ing curve, noted $(J C)$, in the $(\theta, a)$ space (Figure 2$)$.

\section{Comparative Statics}

In this section, we study the effects of minimum wage and unemployment benefits on variables of the model and particulary on job complexity. In the first step, we start by the analytical study of these effects. Then, we resort to quantitative analysis in order to confirm the analytical results and to lift the indetermination. 


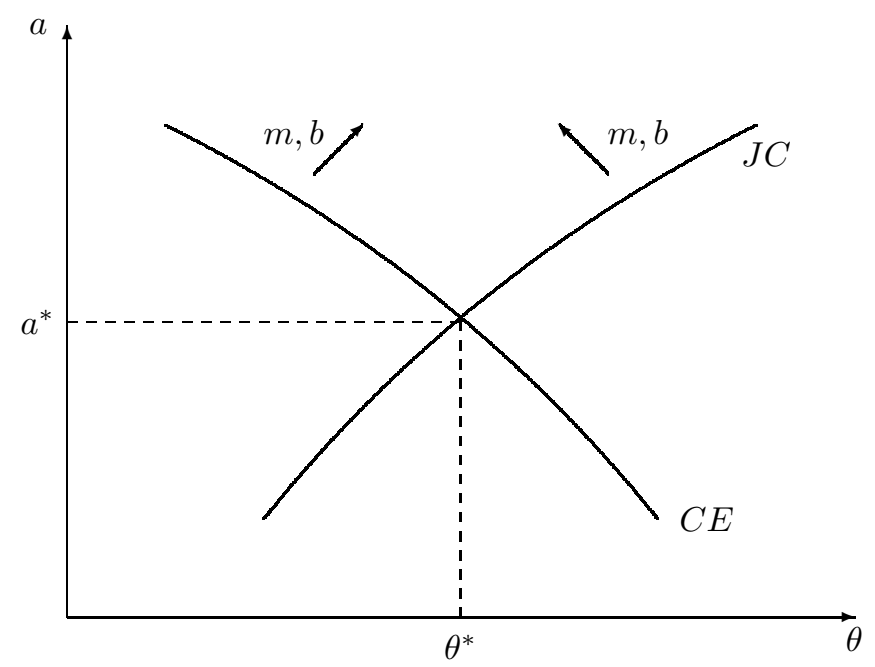

Figure 2: The Labour Market Equilibrium

\subsection{Minimum Wage Effects}

We use Figure 2 in order to simplify the study of minimum wage effects. We first consider the $C E$ curve. As noted above, an increase in minimum wage has a positive impact on the minimal productivity $y(a, \hat{z})$. Also, according to equation (32), a rise in $m$ leads to an increase in complexity $a$, for a given level of $\theta$. In other words, an increase in minimum wage $m$ shifts up the $C E$ curve. We can also see that a rise in $m$ also shifts the $J C$ curve up (Figure 2).

To resume, the graphical study shows that the minimum wage increases job complexity by increasing the threshold ability, thus by reducing the labour market participation.

In addition, taking into account of equations (13) and (27), we show that average productivity is an increasing function of complexity :

$$
d \bar{y}=\beta d a\left[\frac{\left(G\left(z^{m}\right)-G(\hat{z})\right)\left(\bar{z}-\int_{\hat{z}}^{z^{m}} z g(z) d z\right)}{1-G(\hat{z})-\beta\left(1-G\left(z^{m}\right)\right)}\right]+d \hat{z} \frac{g(\hat{z})(\bar{y}-y(a, \hat{z}))}{1-G(\hat{z})}
$$

This increase in complexity and agents selectivity, leads to making matches more productive and more efficient, and hence rise in the productivity $(\bar{y})$. We 
summarize the effects of increasing minimum wage on various parameters in the following table:

\begin{tabular}{|c|c|c|c|c|c|c|c|c|c|c|}
\hline & $\theta$ & $\hat{z}$ & $a$ & $z^{m}$ & $\bar{y}$ & $\bar{w}$ & $p(\theta)$ & $q(\theta)$ & $u$ & $\tau=1-G(\hat{z})$ \\
\hline$m$ & $?$ & + & + & $?$ & + & $?$ & $?$ & $?$ & $?$ & - \\
\hline
\end{tabular}

Table 1: Minimum Wage Effects

The impact of minimum wage on unemployment is ambiguous. Although that the increase in productivity stimulates job creation, low productivity of workers receiving minimum wage would slow down job creation.

\subsection{Unemployment Benefits Effects}

We re-examine Figure 2 in order to study the impact of unemployment benefits on the model variables.

First, consider the $C E$ curve. By differentiation of the equilibrium equation (32), we can easily verify that, for a given level of $\theta$, a rise in unemployment benefits affects job characteristics. The latter become more complex. Graphically, this increase in $b$ shifts up the $C E$ curve (Figure 2).

According to the equilibrium equation (35), we deduce that, for a given level of complexity $a$, an improvement in the unemployment benefits stimulates the job creation by raising $\theta$. This can be explained by the fact that unemployment benefits make agents more selective and thus matching more productive. Graphically, this impact is represented by an upward shift in the $J C$ curve (Figure 2).

In summary, according to the graphical study, agents become more selective about matching quality by requiring a high threshold ability. As a consequence, firms adapt their technological choice $(a)$ to qualified workers, reinforcing the positive impact of unemployment benefits on the average productivity $(\bar{y})$.

Table 2 summarizes unemployment benefits effects on the model parameters: 


\begin{tabular}{|c|c|c|c|c|c|c|c|c|c|c|}
\hline & $\theta$ & $\hat{z}$ & $a$ & $z^{m}$ & $\bar{y}$ & $\bar{w}$ & $p(\theta)$ & $q(\theta)$ & $u$ & $\tau=1-G(\hat{z})$ \\
\hline$b$ & $?$ & + & + & $?$ & + & $?$ & $?$ & $?$ & $?$ & - \\
\hline
\end{tabular}

Table 2: Unemployment Benefits Effects

As in the minimum wage case, although that matching becomes more productive and efficient, the impact on unemployment rate is ambiguous.

\section{Quantitative Analysis}

In the framework of comparative static study, we have obtained contradictory effects of minimum wage and unemployment benefits. In this section, we try to lift ambiguity concerning these effects and to evaluate the consequences on unemployment rate. We note that this model is calibrated in order to represent a situation similar to the French economy.

In accordance with current real rate, the annual rate of time preference is estimated at $5 \%$. The job destruction rate is fixed at 0.15 in order to represent an employment flow compatible with the French situation.

We use a Cobb-Douglas function of the form $\pi(\theta)=h \theta^{\eta}$ to represent the matching function. In accordance with standard matching models (Cahuc and Lehmann, 2000; Mortensen and Pissarides, 1999), we choose an elasticity, noted $\eta$, of this function with respect to vacant job equal to 0.5 . The bargaining power is fixed at 0.5. The Hosios condition is hence satisfied. Unemployment benefits, which are funded by a neutral tax, represent $50 \%$ of wage, while domestic productivity is fixed at $5 \%$. In this economy, for a minimum wage level equal to 0.6 , unemployment rate reaches $11.46 \%$. Parameter values are summarized in table 3 .

\begin{tabular}{|c|c|c|c|c|c|c|c|}
\hline$r$ & $s$ & $\beta$ & $\eta$ & $h$ & $c$ & $b$ & $\mu$ \\
\hline 0.05 & 0.15 & 0.5 & 0.5 & 1.1 & 0.35 & 0.5 & 0.1 \\
\hline
\end{tabular}

Table 3: The Model Calibration 
For these simulations, we assume that the complexity function $A(a)$ is quadratic $\left(A(a)=-a^{2}\right)$. Qualification level is distributed among workers according to a continuous distribution, $G(z)$, with $G(z)=\alpha\left(z-z_{\min }\right)$.

Figure 3 illustrates the minimum wage effects on the variables of the model. As we have shown in the comparative statics section, a rise in minimum wage affects agents selectivity by requiring a higher ability threshold, and hence a higher level of $\hat{z}$. Analytically, this impact is deduced from equilibrium equation (23) which implies that a rise in $m$ leads to a proportional rise in $y(a, \hat{z})$.

Consequently, the probability of a firm meeting a qualified worker becomes higher. As a result, firms adapt their technological choice to qualified workers by creating more complex jobs. However, the labour market participation decreases since the proportion of excluded workers (who have low productivity) rises. This result differs from Acemoglu and Pischke (2003). They show that wage regulation could lead firms to redirect training effort to less qualified workers.

As a result of this technological choice, oriented to higher job complexity, matching becomes more productive and efficient, increasing average productivity and wage. In addition, it seems that this matching quality improvement makes job creation more profitable and leads to a rise in labour market tightness (Figure 3).

As a consequence, the probability $p(\theta)$ for employable workers to find a job increases and the unemployment rate decreases. Nevertheless, firms will have more difficulties to fill their job, as $q(\theta)$ decreases. In addition, it appears that a rise in the minimum wage has a positive effect on the ability transition $z^{m}$ increasing the proportion of workers receiving this minimum wage.

Other papers have achieved similar results with respect to a positive impact of minimum wage on job quality (Edagbami, 2006; Neumark and Washer, 2007). However, the originality and the particularity of our model, reside in the choice of complexity which endogenizes productivity inequalities of workers. Within this framework, we introduce a minimum wage which improves matching quality by affecting not only agents selectivity (as Acemoglu (2001)), but also firms' complexity choice.

Let's now evaluate the effects of unemployment benefits on productivity and on unemployment rate in the presence of a minimum wage fixed at $0.7(m=0.7)$. The results of these simulations are summarized in the Figure 4. 
In accordance with our remark about the equilibrium equation (32), an increase in unemployment benefits, which reinforces the workers bargaining power, leads to a rise in bargained wages and to a decrease in the proportion of workers receiving minimum wage (fall of $z^{m}$ ). As we have shown in the comparative statics section, that firms choose to create more complex job in favor of qualified workers whose recruiting becomes more easier. Although, matching quality becomes more efficient and average productivity increases, the labour market participation falls.

In addition, we obtain a negative impact of unemployment benefits on the labour market tightness. In spite of average productivity improvement, a decrease in value of filled jobs could brake the job creation process. Firms are less incited to enter the labour market since prospective profits decrease.

A decrease in the labour market tightness raises both the probability of meeting a worker $q(\theta)$ and the unemployment rate. On the contrary, employable workers have more difficulties to find a job.

Other papers (Acemoglu and Shimer, 1999, 2000; Diamond, 1981; Ljungqvist and Sargent, 1995) show that unemployment benefits, which allow workers to better choose their job, improve job quality and global productivity. In the same mind, Marimon and Zilibotti (1999) show that, in a matching model with horizontal differentiation of agents, an increase in unemployment benefits leads to a better adaptation of skills to firms needs. On the contrary, in our model, productivity effect of unemployment benefits is not only due to selectivity but also to endogenous technological choice. 

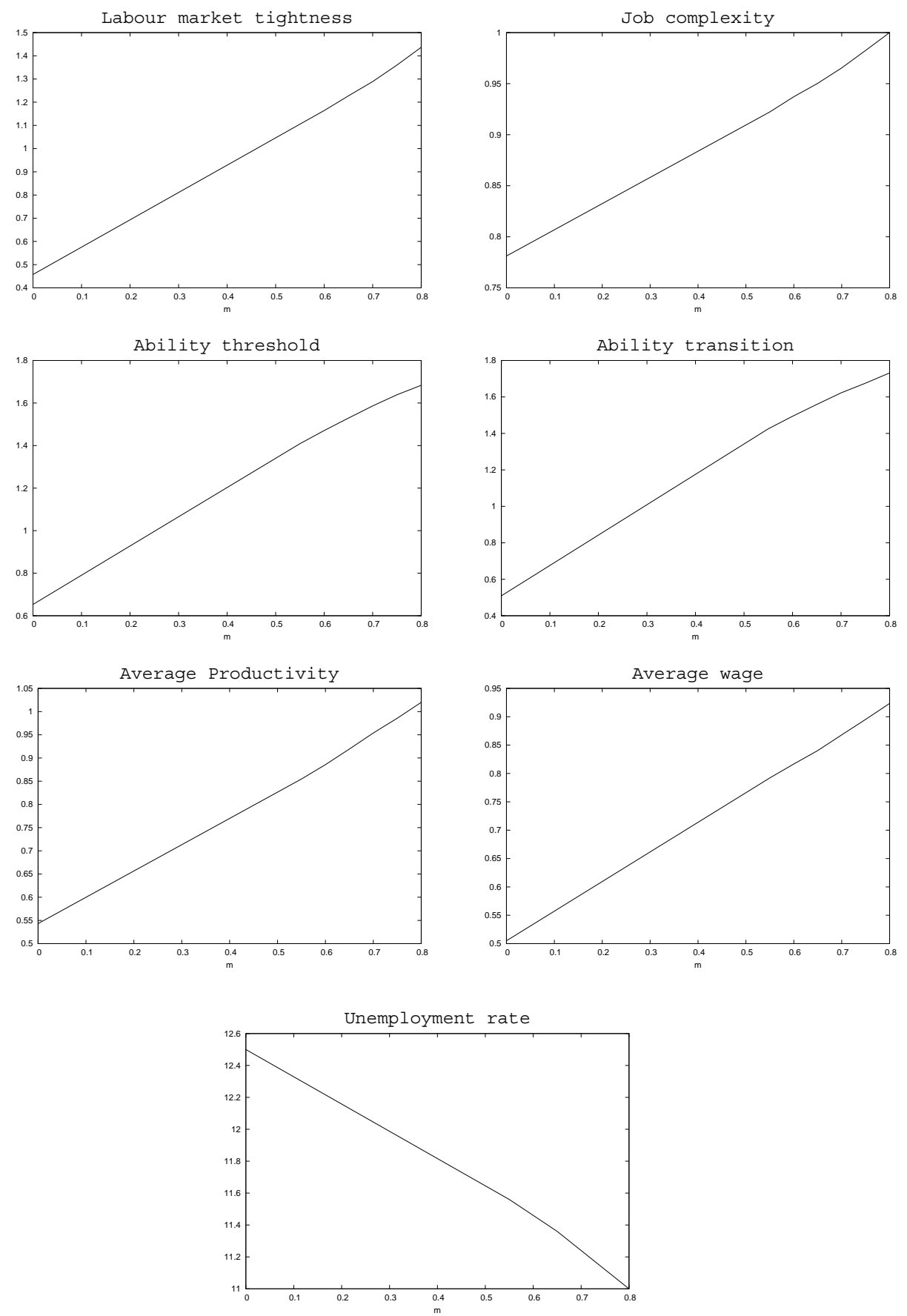

Figure 3: Impact of the Minimum Wage on Model Variables 

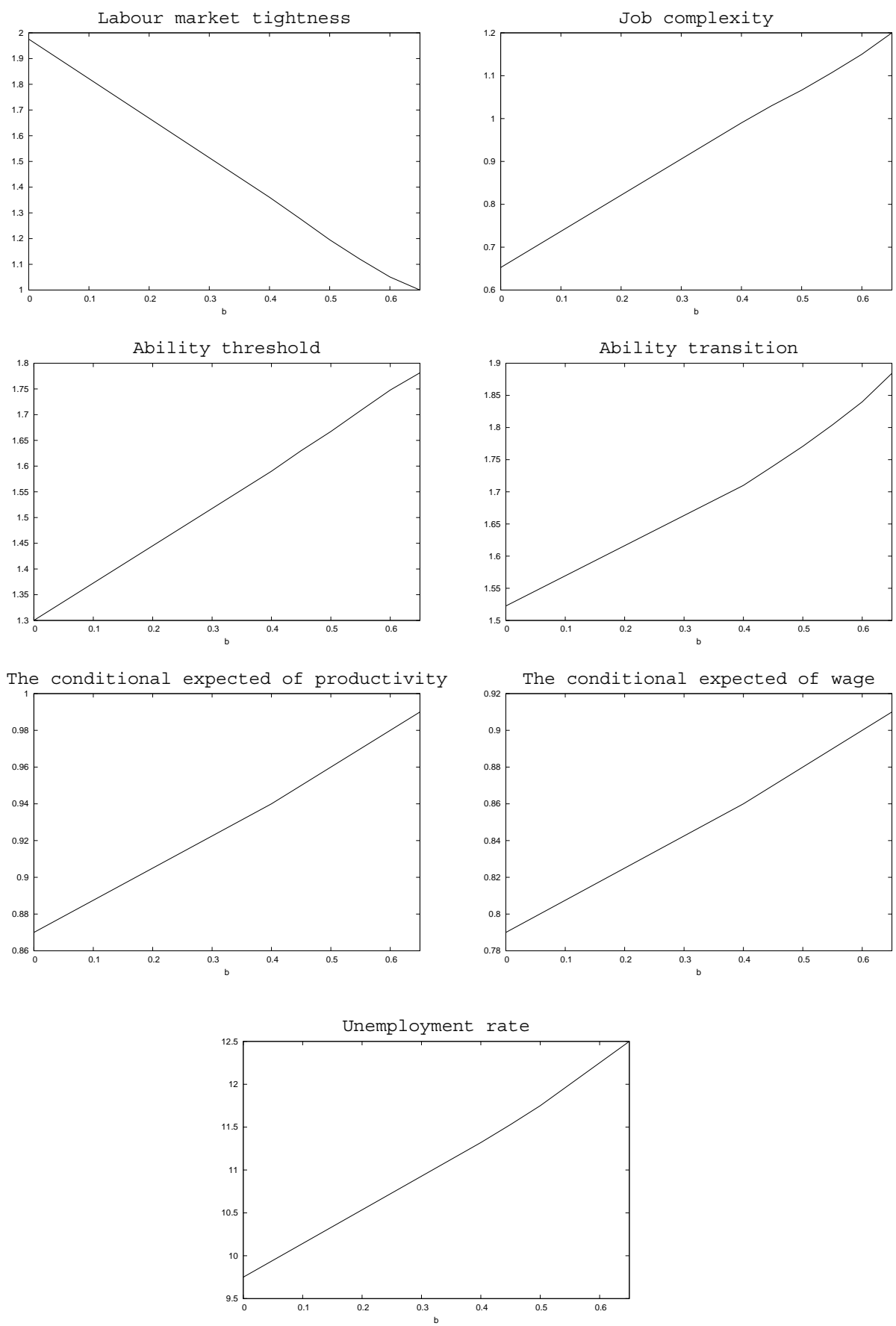

Figure 4: Impact of Unemployment Benefits on Model Variables 


\section{Conclusion}

This paper aims at understanding interactions between labour market performance and public policies used to reduce inequalities. Within an economy in which the nature of jobs is endogenous, we analyze the consequences of adopting and increasing the minimum wage and unemployment benefits. These instruments are generally considered as source of labour market inflexibility.

Considering that job complexity results from firm choice, we have obtained two mains results. The first one is related to minimum wage impact on job quality and labour market participation. We have shown, in the second result, that unemployment benefits lead to a fall in job creation and to productivity improvement.

Indeed, we have shown that raising minimum wage affects simultaneously firms' behavior for recruiting and jobs characteristics. Against this public policy, firms require a higher minimal qualification and create more complex jobs. In spite of productivity improvement, labour market participation decreases. To summarize, the introduction of minimum wage reduces the size of economy by making it more competitive.

The presence of minimum wage reverses unemployment benefits effects on the labour market participation and on the complexity. Without minimum wage, the rise in unemployment benefits affects directly labour market participation by increasing minimal qualification level. On the contrary, with the presence of a minimum wage, the direct effect is on job complexity and the fall in participation is only a consequence. In other words, in the presence of a minimum wage, unemployment benefits act on participation only when job complexity is endogenous. This clearly shows the limits of an approach which considers nature of jobs as being exogenous. 


\section{References}

[1] Acemoglu, D., 1998. Why do new technologies complement skills ? directed technical change and wage inequality. Quarterly Journal of Economics 113, 1055-1090.

[2] Acemoglu, D., 1999. Changes in unemployment and wage inequality : An alternative theory and some evidence. American Economic Review 89, 12591278 .

[3] Acemoglu, D., 2001. Good jobs versus bad jobs. Journal of Labour Economics 19, 1-22.

[4] Acemoglu, D., 2002. Technical change, inequality and the labour market. Journal of Economic Literature 40, 7-73.

[5] Acemoglu, D., 2003. Patterns of skill premia. Review of Economic Studies $70,199-230$.

[6] Acemoglu, D., Pischke, J.S., 2003. Minimum wage and on-the-job training. Research in Labor Economics 22, 159-202.

[7] Acemoglu, D., Shimer, R., 1999. Efficient unemployment insurance. Journal of Political Economy 107, 893-928.

[8] Acemoglu, D., Shimer, R., 2000. Productivity gains from unemployment insurance. European Economic Review 44, 1195-1224.

[9] Aghion, P., Howitt, P., 2002. Wage inequality and the new economy. Oxford Review of Economic Policy 18, 306-323.

[10] Albrecht, J.W., Vroman, S.B., 2002. Matching model with endogenous skill requirements. International Economic Review 43, 283-305. 
[11] Amine, S., 2006. Technological choices and unemployment benefits in a matching model with heterogenous workers. University of Ottawa, Working paper.

[12] Autor, D.H., Katz, L.F., Krueger, A.B., 1998. Computing inequality : have computers changed the labor market?. Quarterly Journal of Economics 113, 1169-1214.

[13] Berman, E., Bound, J., Griliches, Z., 1999. Changes in the demand for skilled labor within U.S. manufacturing industries: evidence from the annual survey of manufactures. Quarterly Journal of Economics 109, 367-397.

[14] Bound, J., Johnson, G., 1992. Changes in the structure of wages in the 1980s : an evaluation of alternative explanations. American Economic Review $82,371-392$.

[15] Cahuc, P., Lehmann, E., 2000. Should unemployment benefits decrease with unemployment spell ?. Journal of Public Economics 77, 135-153.

[16] Decreuse, B., Granier, P., 2005. Adaptabilité et complexité, les choix éducatifs et technologiques sont-ils efficaces?. Revue Economique 56, 551-562.

[17] Diamond, P.A., 1981. Mobility costs, frictional unemployment, and efficiency. Journal of Political Economy 89, 798-812.

[18] Edagbami, O., 2006. The employment effects of the minimum wage: A review of the literature. Canadian Policy Research Networks.

[19] Funk, P., Vogel, T., 2004. Endogenous skill bias. Journal of Economic Dynamics and Control 28, 2155-2193.

[20] Gautier, P.A., 1999. Unemployment and search externalities in a model with heterogeneous jobs and heterogeneous workers. Tinbergen Institute Discussion Paper $n^{\circ}$ 99-075/3. 
[21] Gautier, P.A, Teulings, C., 2004. The Right Man for the Job. Review of Economic Studies 71, 553-580.

[22] Krugman, P.R., 1993. Inequality and the political economy of eurosclerosis. CEPR Discussion Paper n ${ }^{\circ} 867$.

[23] Lehmann, E., 1999. L'impact de l'assurance chômage et de l'assistance chômage sur le chômage d'équilibre. Annales d'Économie et Statistiques 53, $31-41$.

[24] Ljungqvist, L., Sargent, T., 1995. The swedish unemployment experience. European Economic Review 39, 1043-1070.

[25] Manacorda, M., Petrongolo, B., 1999. Skill mismatch and unemployment in OECD countries. Economica 66, 181-207.

[26] Marimon, R., Zilibotti, F., 1999. Unemployment vs mismatch of talents : reconsidering unemployment benefits. Economic Journal 109, 266-291.

[27] Mortensen, D.T., Pissarides, C., 1999. Unemployment response to "skill biased" shocks : the role of labour market policy. Economic Journal 109, 242-265.

[28] Neumark, D., Wascher, W., 2007. Minimum wages and employment. Foundations and Trends in Microeconomics 3, 1-182.

[29] Nickell, S., 2004. Poverty and worklessness in Britain. Economic journal 114, 1-25.

[30] Pissarides, C.A., 2000. Equilibrium unemployment theory. Cambridge: MIT Press.

[31] Strand, J., 2000. Wage bargaining and turnover costs with heterogeneous labor and asymmetric information. Labour Economics 7, 95-116. 
[32] Strand, J., 2002. Wage bargaining and turnover costs with heterogeneous labour and perfect history screening. European Economic Review 46, 12091227. 